\title{
KAJIAN BAHAYA RADIASI TERHADAP NORM DALAM SEDIMEN PERMUKAAN DI LINGKUNGAN DAS CISADANE HULU DAN CIUJUNG HULU
}

\section{EVALUATION OF RADIATION HAZARDS TO NORM IN SEDIMENT SURFACE IN THE CISADANE HULU AND CIUJUNG HULU}

\author{
Tommy Hutabarat \\ Pusat Aplikasi Isotop dan Radiasi (PAIR), BATAN \\ Jl. Cinere Pasar Jumat, Jakarta Selatan, Kotak Pos 7002 JKSKL, Jakarta 12070 \\ e-mail : tevarito@batan.go.id
}

Diterima: 16 Mei 2018, diperbaiki : 18 Mei 2018, disetujui : 25 Mei 2018

\begin{abstract}
ABSTRAK
KAJIAN BAHAYA RADIASI TERHADAP NORM DALAM SEDIMEN PERMUKAAN DI LINGKUNGAN DAS CISADANE HULU DAN CIUJUNG HULU. Manusia secara terus menerus terpapar radiasi karena kehadirannya dimana - mana di bumi. NORM berpotensi memberikan dampak radiologi baik berupa pajanan radiasi eksterna maupun interna. Penelitian ini bertujuan untuk menentukan konsentrasi radioaktivitas NORM dalam sedimen sungai pada DAS Cisadane Hulu dan DAS Ciujung Hulu. Pengambilan sampel permukaan endapan sedimen dilakukan menggunakan scrapper. Seluruh sampel dikeringkan pada suhu kamar selama 3-4 hari. Setelah kering, sampel digerus halus (200 mesh) menggunakan mortar, kemudian diayak dan ditimbang secara seksama sebanyak $0,5 \mathrm{~kg}$ dan dimasukkan ke dalam tabung plastik polietilen dan di-seal. Pengukuran radionuklida U-238 dan Th-232 beserta turunannya dan radionuklida K-40 dilakukan menggunakan spektrometer gamma. Konsentrasi radionuklida alam U-238, Th-232, dan K-40 yang diperoleh dari ke dua lokasi DAS sangat kecil dibawah baku mutu yaitu sebesar $25 \mathrm{~Bq} / \mathrm{kg}$ dan masih dibawah rata-rata dunia. Sebaran konsentrasi U-238 di kedua lokasi berkisar antara 6,38 - 17,67 Bq/kg, konsentrasi aktivitas Th-232 dan K40 masing-masing berkisar anatara 11,56-23,45 Bq/kg dan 49,76-289,65 Bq/kg. Nilai Ra eq pada ke dua lokasi DAS berkisar antara 34,799 - 56,912 Bq/kg masih dibawa batas yang direkomemdasikan oleh UNSCEAR yaitu sebesar $370 \mathrm{~Bq} / \mathrm{kg}$. Nilai indeks bahaya radiasi ly2, indeks bahaya radiasi internal (Ibi), dan indeks bahaya radiasi eksternal (Ibe) di kedua lokasi DAS masing-masing < 1 sehingga masih aman terhadap manusia. Dari hasil uji statistik terhadap parameter Ra eq dan tingkat bahaya radiasi tidak terdapat perbedaan yang signifikan antara ke dua lokasi DAS.
\end{abstract}

Kata kunci :NORM, sedimen, indek bahaya radiasi

\section{ABSTRACT}

EVALUATION OF RADIATION HAZARDS TO NORM IN SEDIMENT SURFACE IN THE CISADANE HULU AND CIUJUNG HULU. Humans are constantly exposed to radiation because of its presence everywhere on earth. NORM has the potential to provide radiological impacts either in the form of external and internal radiation exposure. This study aims to determine the concentration of NORM radioactivity in river sediments in Cisadane Hulu Watershed and Ciujung Hulu Watershed. Sampling of the sediment of the surface is carried out using scrapper. The entire sample is dried at room temperature for 3-4 days. After drying, a fine smeared sample (200 mesh) uses mortar, then sieved and carefully weighed as much as $0.5 \mathrm{~kg}$ and inserted into a polyethylene plastic tube and seal. Measurements of radionuclides U-238 and Th-232 along with their derivatives and $K-40$ radionuclides were performed using a gamma 
spectrometer. The concentrations of natural radionuclides U-238, Th-232, and K-40 obtained from the two watershed locations are very small below the $25 \mathrm{~Bq} / \mathrm{kg}$ standard and still below the world average. The distribution of $U-238$ concentrations in both locations ranged from 6.38 to $17.67 \mathrm{~Bq} / \mathrm{kg}$, the concentration of Th-232 and K-40 activity ranged between $11.56-23.45 \mathrm{~Bq} / \mathrm{kg}$ and $49.76-289.65 \mathrm{~Bq} / \mathrm{kg}$. The value of $\mathrm{Ra}$ eq in the two watershed locations ranged from $34.799-56.912 \mathrm{~Bq} / \mathrm{kg}$ was still brought to the limit recommended by UNSCEAR of $370 \mathrm{~Bq} / \mathrm{kg}$. Iye radiation hazard index values, internal radiation hazard index (Ibi), and external radiation hazard index (Ibe) in both watershed locations $<1$ each are still safe against humans. From the result of statistical test on $\mathrm{Ra}$ eq parameter and radiation hazard level there is no significant difference between the two watershed locations.

Key words : NORM, sediments, hazards index

\section{PENDAHULUAN}

$\mathrm{D}$ egradasi sumber daya tanah dan lingkungan merupakan masalah yang dihadapi oleh banyak negara termasuk Indonesia. Batuan sedimen pada permukaan bumi akan mengalami pelapukan yang kemudian akan terkikis oleh air hujan sebagai akibat dari proses fisika dan kimia. Sedimen lepas yang terangkut bersama air hujan akan bergerak menuju sungai sebagai tempat pembuangan akhir sebelum menuju ke laut. Menurut Wigman, $1970{ }^{[1]}$ sedimen didefinisikan sebagai setiap serpihan material yang terangkut, tersuspensi atau terdeposisi oleh media seperti air, udara atau es.

Bahan radioaktif alami (NORM) dari deret uranium-238, deret thorium232 dan potassium-40 terdapat dimana- mana di kerak bumi. Konsentrasi radionuklida ini tergantung pada komposisi tanah dan batuan. Semua nuklida ini menghasilkan dosis radiasi untuk semua makhluk hidup. Peluruhan radioaktif U-238 dan Th-232 menghasilkan beberapa rangkaian anak luruh yang berbeda unsur dan karakteristik fisiknya sehubungan dengan waktu paro, bentuk peluruhan, jenis dan energi radiasi yang dipancarkan ${ }^{[2]}$. U238 dan Th-232 mempunyai umur paro yang sangat panjang (milyaran tahun) dan dalam proses peluruhannya akan menghasilkan berbagai macam anak luruh dengan umur paro dari orde detik sampai ribuan tahun seperti yang disajikan pada Tabel 1.

Tabel 1. Deret U -238 danTh-232 bersama anak luruhnya ${ }^{[3]}$

\begin{tabular}{lll}
\hline Unsur & Waktu paro & Mode peluruhan \\
\hline U-238 & $4,5 \times 10^{9}$ tahun & alfa \\
Th-234 & 24,10 hari & beta \\
Pa-234m & 1,2 menit & beta \\
U-234 & $2,5 \times 10^{5}$ tahun & alfa \\
Th-230 & $7,7 \times 10^{4}$ tahun & alfa \\
Ra-226 & $1,6 \times 10^{3}$ tahun & alfa \\
Rn-222 & 3,8 hari & alfa \\
Po-218 & 3,05 menit & alfa \\
Pb-214 & 26,8 menit & beta \\
Bi-214 & 19,9 menit & beta
\end{tabular}




$\begin{array}{lll}\mathrm{Po}-214 & 1,6 \times 10^{-4} \text { detik } & \text { alfa } \\ \mathrm{Pb}-210 & 22,3 \text { tahun } & \text { beta } \\ \mathrm{Bi}-210 & 5 \text { hari } & \text { beta } \\ \mathrm{Po}-210 & 138 \text { hari } & \text { alfa } \\ \mathrm{Pb}-206 & \text { stabil } & \\ \mathrm{Th}-232 & 1,4 \times 10^{10} \text { tahun } & \text { alfa } \\ \mathrm{Ra}-228 & 5,8 \text { tahun } & \text { beta } \\ \mathrm{Ac}-228 & 6,13 \text { jam } & \text { beta } \\ \mathrm{Th}-228 & 1,9 \text { tahun } & \text { alfa } \\ \mathrm{Ra}-224 & 3,64 \text { hari } & \text { alfa } \\ \mathrm{Rn}-220 \text { (gas) } & 55 \text { detik } & \text { alfa } \\ \mathrm{Po}-216 & 0,15 \text { detik } & \text { alfa } \\ \mathrm{Pb}-212 & 10,6 \text { jam } & \text { beta } \\ \mathrm{Bi}-212 & 60,6 \text { menit } & \text { alfa, beta } \\ \mathrm{T}-208 & 3,1 \text { menit } & \text { beta } \\ \mathrm{Po}-212 & 3 \times 10^{-7} \text { detik } & \text { alfa } \\ \mathrm{Pb}-208 & \text { stabil } & \end{array}$

Sumber kegiatan manusia yang dapat membantu menyebarkan zat radioaktif ke lingkungan adalah pertanian, pertambangan dan industri. Unsur radioaktif yang terdapat pada sebagian besar pupuk kimia (fosfat, NPK, KCl) terutama pupuk yang mengandung fosfat, pada umumnya adalah unsur radioaktif alam yang mempunyai waktu paro sangat panjang. Unsur radioaktif tersebut antara lain adalah Uranium, Torium, dan Kalium sehingga dalam jangka waktu lama akan terjadi penumpukan atau akumulasi di alam ${ }^{[4]}$. Analisis zat radioaktif yang terkandung dalam sedimen dilakukan menggunakan alat spektrometer gamma yang dilengkapi dengan detektor semikonduktor HPGe (High Pure Germanium), MCA (Multi Channel Analyzer) yang mempunyai 8000 salur dan perangkat lunak Gennie 2000 untuk analisis kualitatif dan kuantitatif. Pengukuran radionuklida U-238 dan Th232 dalam sampel sedimen dilakukan dengan metode pasif. Pada penentuan secara pasif, aktivitas unsur radionuklida
U-238 dihitung berdasarkan aktivitas anak luruhnya yaitu $\mathrm{Pb}-214$ dan $\mathrm{Bi}-214$ yang memancarkan radiasi gamma masing-masing pada energi $352 \mathrm{keV}$ dan 609 keV dengan $\mathrm{Py}=37 \%$ dan $45 \%$. Radionuklida alam Th-232 dihitung berdasarkan aktivitas spesifik $\mathrm{Pb}-212$ dan Ac-228 yang memancarkan radiasi gamma pada energi 238,63 keV dan 911 keV dengan kelimpahan $\mathrm{Py}=43 \%$ dan $25 \%$. Demikian juga untuk radionuklida $\mathrm{K}-40$ dihitung langsung pada energi 1460,83 keV dengan $P Y=10,67 \%$ [5].

\section{BAHAN DAN METODE}

Pengambilan sampel

Sampel sedimen sungai DAS Ciujung Hulu diambil dari lokasi muara sungai Ciberang dan Ciujung, sungai Ciberang, sungai Cisemeut, dan sungai Ciujung (tabel 2), sedangkan pada sedimen sungai DAS Cisadane Hulu diambil dari lokasi sungai Cisadane Hulu; sungai Cianten; sungai Cikaniki; muara sungai Cianten-Cikaniki; dan sungai Cisadane Hilir (tabel 3). 
Tabel 2. Lokasi titik pengambilan sampel sedimen DAS Ciujung Hulu

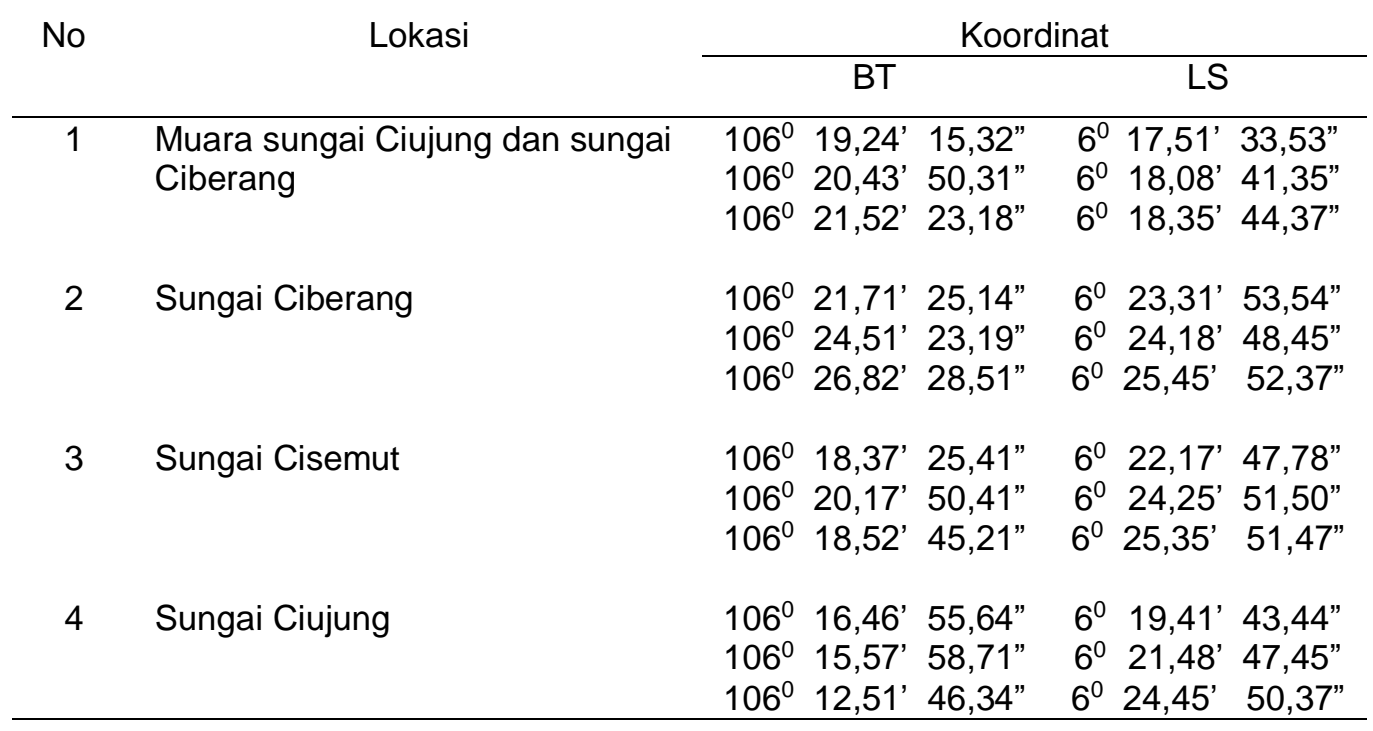

Tabel 3. Lokasi titik pengambilan sampel sedimen DAS Cisadane Hulu

\begin{tabular}{|c|c|c|c|}
\hline \multirow[b]{2}{*}{ No } & \multirow[b]{2}{*}{ Lokasi } & \multicolumn{2}{|c|}{ Koordinat } \\
\hline & & BT & LS \\
\hline 1 & Sungai Cisadane hulu & $\begin{array}{c}106^{0} 47,35^{\prime} \\
31,57^{\prime \prime} \\
106^{0} 45,53^{\prime} \\
30,35^{\prime \prime} \\
106^{0} 40,92^{\prime} \\
27,28^{\prime \prime}\end{array}$ & $\begin{array}{c}6^{0} 33,71^{\prime} \\
43,14^{\prime \prime} \\
6^{0} 31,78^{\prime} \\
41,85^{\prime \prime} \\
6^{0} 29,85^{\prime} \\
40,57^{\prime \prime}\end{array}$ \\
\hline 2 & Sungai Cianten & $\begin{array}{c}106^{0} 37,71^{\prime} \\
25,14^{\prime \prime} \\
106^{0} 37,71^{\prime} \\
25,14^{\prime \prime} \\
106^{0} 37,82^{\prime} \\
25,21^{\prime \prime}\end{array}$ & $\begin{array}{c}6^{0} \quad 33,71^{\prime} \\
43,14^{\prime \prime} \\
6^{0} 31,78^{\prime} \\
41,85^{\prime \prime} \\
6^{0} \quad 29,85^{\prime} \\
40,57^{\prime \prime}\end{array}$ \\
\hline 3 & Sungai Cikaniki & $\begin{array}{c}106^{0} 32,57^{\prime} \\
21,71^{\prime \prime} \\
106^{0} 35,57^{\prime} \\
23,71^{\prime \prime} \\
106^{0} 37,82^{\prime} \\
25,21^{\prime \prime}\end{array}$ & $\begin{array}{cc}6^{0} \quad 30,17^{\prime} \\
40,78^{\prime \prime} \\
6^{0} 31,25 \\
41,50^{\prime \prime} \\
6^{0} 31,35^{\prime} \\
41,57^{\prime \prime}\end{array}$ \\
\hline
\end{tabular}


$4 \quad$ Muara Cikaniki - Cianten

5 Sungai Cisadane hilir

$\begin{array}{cc}106^{0} 38,46^{\prime} & 6^{0} 31,35^{\prime} \\ 25,64^{\prime \prime} & 41,57^{\prime \prime} \\ 106^{0} 38,57^{\prime} & 6^{0} 30,25^{\prime} \\ 25,71^{\prime \prime} & 40,50^{\prime \prime} \\ 106^{0} 39,21^{\prime} & 6^{0} 29,85^{\prime} \\ 26,14^{\prime \prime} & 40,57^{\prime \prime} \\ 106^{0} 38,35^{\prime} & 6^{0} 26,64^{\prime} \\ 25,57^{\prime \prime} & 38,42^{\prime \prime} \\ 106^{0} 39,42^{\prime} & 6^{0} 27,50 \\ 26,28 " & 39,00^{\prime \prime} \\ 106^{0} 39,64^{\prime} & 6^{0} 28,46 \\ 26,42^{\prime \prime} & 39,64 "\end{array}$

Sampel sedimen berupa sedimen suspensi kering atau basah yang terjebak oleh batuan akibat berkurangnya debit aliran. Sampel sedimen diambil pada periode bulan April s/d Oktober 2017. Pengambilan sampel permukaan endapan sedimen dilakukan secara acak disekitar titik lokasi menggunakan sendok semen. Sebanyak $1 \mathrm{~kg}$ sampel sedimen suspensi setiap titik lokasi dimasukkan ke dalam kantong plastik dan diberi kode, kemudian dibawa ke laboratorium untuk dilakukan preparasi selanjutnya.

\section{Bahan}

Bahan yang digunakan dalam penelitian adalah beberapa sampel sedimen suspensi yang mewakili anak sungai; sungai utama dan muara sungai, standar yang mengandung unsur radioaktif berenergi rendah hingga tinggi (Sea sediment IAEA-300), nitrogen cair; software pencacah dan pengolah data Gennie 2000 dan bahan pendukung lainnya.

\section{Peralatan \\ Peralatan yang digunakan adalah seperangkat spektrometer gamma buatan Canberra yang dilengkapi dengan detektor semikonduktor HPGe (High Pure Germanium), MCA (Multi}

Channel Analyzer); timbangan; ayakan dan sendok semen.

\section{Metode Analisis}

Masing-masing sampel digerus halus ( 200 mesh) menggunakan mortar, kemudian diayak dan ditimbang secara seksama sebanyak 0,5 kg dan dimasukkan kedalam tabung plastik polietilen dan di- seal. Sampel dibiarkan selama \pm 1 bulan agar terjadi kesetimbangan. Sebelum pengukuran sampel, terlebih dahulu dilakukan kalibrasi yang meliputi kalibrasi energi dan kalibrasi efisiensi. Kalibrasi energi dilakukan dengan mencacah radionuklida yang telah diketahui energinya, kemudian dibuat kurva hubungan antara nomor salur (channel) versus energi gamma (keV). Kalibrasi efisiensi dilakukan dengan mencacah sumber standar yang telah diketahui aktivitasnya dan kemudian ditentukan efisiensi tiaptiap puncak energi gamma yang teramati, selanjutnya dapat dibuat kurva hubungan antara energi gamma (keV) versus efisiensi.

Penentuan nilai efisiensi setiap energi dihitung dengan mengukur cacahan sumber standar yang telah diketahui aktivitasnya menggunakan persamaan sebagai berikut: 
$\varepsilon_{y}=\left(C p s_{s}-C p s b g\right) / A_{t} \times \rho_{y}$ dimana :

$$
\begin{aligned}
& \varepsilon_{\mathrm{Y}}= \begin{array}{l}
\text { nilai efisiensi pada setiap } \\
\text { energi dari standar Eu-152 } \\
(\%)
\end{array} \\
& \mathrm{Cps}=\begin{array}{l}
\text { cacah standar dan cacah } \\
\text { latar }
\end{array} \\
& \mathrm{A}_{\mathrm{t}}=\begin{array}{l}
\text { aktivitas standar saat } \\
\text { pengukuran (dps) }
\end{array} \\
& \rho_{\mathrm{Y}}=\begin{array}{l}
\text { kelimpahan energi gamma } \\
\text { standar Eu-152 (\%) }
\end{array}
\end{aligned}
$$

Dari kurva efisiensi akan diperoleh nilai efisiensi setiap energi yang diperlukan untuk menghitung aktivitas radionuklida dalam sampel. Langkah selanjutnya sampel dicacah menggunakan detektor HPGE yang terhubung dengan Multi channel Analyzer. Setiap sampel dicacah selama 24 jam.

Perhitungan aktifitas spesifik radionuklida alam dalam sampel menggunakan rumus:

$A_{s}=\left\{\left(N_{1}-N_{b}\right) \pm \sigma\right\} /\left\{\varepsilon \times \rho \times F_{k} \times W\right\}$

dimana :

As = aktifitas spesifik radionuklida $(\mathrm{bq} / \mathrm{kg})$

$\mathrm{N}_{1}=$ laju cacah radionuklidaalam dalam sampel (cps)

$\mathrm{N}_{2}=$ laju cacah radionuklida alam latar (cps)

$\sigma=$ standar deviasi pengukuran

$\varepsilon=$ efisiensi pencacahan

$\rho=$ kelimpahan energi gamma (\%)

$\mathrm{F}_{\mathrm{k}}=$ Faktor koreksi serapan diri

$\mathrm{W}=$ berat sampel $(\mathrm{kg})$

Selanjutnya pencacahan dan hasil cacahan dianalisis menggunakan program Gennie 2000. Faktor koreksi diperlukan bila terjadi perbedaan antara densitas sampel dan standar [6]:

$F_{k}=\frac{\mu t}{1-e^{-\mu t}}$ dimana $: \mu=\mu_{m} \rho$ dan $\mu_{m}=1,287 E^{-0,435}$

dengan :

$$
\begin{aligned}
\mathrm{F}_{\mathrm{k}} & =\text { faktor koreksi serapan diri } \\
\mu & =\text { faktor serapan linier }(\mathrm{cm}-1) \\
\mathrm{t} & =\text { tebal sampel }(\mathrm{cm}) \\
\mu_{\mathrm{m}} & =\text { faktor serapan massa pada } \\
& \text { energi gamma } \\
\mathrm{\rho} & =\text { kerapatan sampel }(\mathrm{g} / \mathrm{cm} 3) \\
\mathrm{E} & =\text { energi gamma }(\mathrm{keV})
\end{aligned}
$$

Aktivitas Radium equivalen ( $\mathrm{Ra}$ eq) merupakan indeks umum yang digunakan untuk membandingkan aktivitas spesifik bahan yang mengandung Ra-226, Th-232, dan K-40 dan secara matematis didefinisikan oleh $[7,8,9]$.

Perhitungan aktivitas Radium ekivalen dilakukan menggunakan rumus:

Ra eq $=$ kons $\mathrm{Ra}+1,43$ kons $\mathrm{Th}+0,077$ kons K-40 dimana:

kons $\mathrm{Ra}+1,43$ kons Th $+0,077$ kons K-40 adalah konsentrasi aktivitas $(\mathrm{Bq} / \mathrm{kg})$ untuk masing - masing Ra-226, Th-232, dan K-40.

Estimasi tingkat bahaya radiasi gamma terkait dengan radionuklida alam dalam sampel sedimen dapat dihitung menggunakan indek bahaya radiasi $\left(\mathrm{I}_{\mathrm{\gamma r}}\right)$ [10].

$\left(\mathrm{I}_{\mathrm{Yr}}\right)=\left(\frac{A_{\text {Ra }}}{150}+\frac{A_{\text {Th }}}{100}+\frac{A_{K}}{1500}\right)$

dimana:

$\mathrm{C}_{\mathrm{Ra}}, \mathrm{C}_{\mathrm{Th}}$ dan $\mathrm{C}_{\mathrm{K}}$ adalah aktivitas spesifik $(\mathrm{Bq} / \mathrm{kg})$ untuk masing-masing Ra-226, Th-232, dan K-40.

Indeks bahaya eksternal ( $\mathrm{lb}_{\mathrm{e}}$ ) merupakan indeks bahaya radiasi yang banyak digunakan untuk paparan eksternal yang didefinisikan sebagai berikut ${ }^{[11]}$ :

$I B e=\left(\frac{A R a}{a 70} 370+\frac{A T h}{259}+\frac{A k}{4910}\right) \leq 1$

Selain indeks bahaya radiasi eksternal, radon dan turunan yang berumur pendek 
juga berbahaya bagi organ pernapasan yang disebut sebagai indeks bahaya internal yang didefinisikan sebagai berikut [11] :

$I B i=\left(\frac{A R a}{a 70} 370+\frac{A T h}{259}+\frac{A k}{4810}\right) \leq 1$

Nilai indeks ( $I B_{e}$ dan $\left.I B_{i}\right)$ harus kurang dari satu untuk keselamatan radiologi [12].

\section{HASIL DAN PEMBAHASAN}

Aktivtas U-238, Th-232, dan K-40 dalam sampel sedimen

Data rerata konsentrasi aktivitas U-238, Th-232, dan K-40 dalam sedimen lokasi DAS Ciujung Hulu dan DAS Cisadane Hulu masing-masing disajikan pada tabel 4 dan 5 . Sebaran konsentrasi U-238 di kedua lokasi berkisar antara $6,38-17,67 \mathrm{~Bq} / \mathrm{kg}$, konsentrasi aktivitas Th-232 dan K-40 masing-masing berkisar antara 11,56 - 23,45 Bq/kg dan 49,76 - 289,65 Bq/kg. Konsentrasi U-238 dan Th-232 di kedua lokasi penelitian masih dibawah nilai rata-rata dunia yaitu sebesar $25 \mathrm{~Bq} / \mathrm{kg}{ }^{[13]}$. Histogram sebaran konsentrasi U-238; Th-232 dan K-40 dalam sedimen yang dicuplik di kedua lokasi DAS dapat dilihat pada gambar 1 dan 2.

Tabel 4. Rerata konsentrasi aktifitas U-238, Th-232, dan K-40 DAS Ciujung Hulu

\begin{tabular}{clccc}
\hline No. & \multicolumn{1}{c}{ Lokasi } & $\begin{array}{c}\mathrm{U}-238 \\
(\mathrm{~Bq} / \mathrm{kg})\end{array}$ & $\begin{array}{c}\text { Th-232 } \\
(\mathrm{Bq} / \mathrm{kg})\end{array}$ & $\begin{array}{c}\mathrm{K}-40 \\
(\mathrm{~Bq} / \mathrm{kg})\end{array}$ \\
\hline 1. & Muara Ciberang-Ciujung & $12,47 \pm 0,20$ & $21,82 \pm 0,24$ & $146,51 \pm 0,53$ \\
2. & Sungai Ciberang & $16,28 \pm 0,33$ & $15,36 \pm 0,49$ & $54,69 \pm 0,45$ \\
3. & Sungai Cisemut & $6,86 \pm 0,45$ & $12,89 \pm 0,25$ & $70,63 \pm 0,31$ \\
4. & Sungai Ciujung & $12,67 \pm 0,39$ & $15,92 \pm 0,53$ & $269,29 \pm 0,52$ \\
\hline
\end{tabular}

Tabel 5. Rerata konsentrasi aktifitas ${ }^{238} \mathrm{U},{ }^{232} \mathrm{Th}$, dan ${ }^{40} \mathrm{~K}$ DAS Cisadane Hulu

\begin{tabular}{clccc}
\hline No. & \multicolumn{1}{c}{ Lokasi } & $\begin{array}{c}\mathrm{U}-238 \\
(\mathrm{bq} / \mathrm{kg})\end{array}$ & $\begin{array}{c}\mathrm{Th}-232 \\
(\mathrm{bq} / \mathrm{kg})\end{array}$ & $\begin{array}{c}\mathrm{K}-40 \\
(\mathrm{bq} / \mathrm{kg})\end{array}$ \\
\hline 1. & Sungai Cisadane Hulu & $9.09 \pm 0,21$ & $14.25 \pm 0,33$ & $55.26 \pm 1,27$ \\
2. & Sungai Cikaniki & $8.87 \pm 0,20$ & $14.24 \pm 0,32$ & $217.65 \pm 5,01$ \\
3. & Sungai Cianten & $6.53 \pm 0,15$ & $12.61 \pm 0,29$ & $72.93 \pm 1,66$ \\
4. & Muara Cikaniki-Cianten & $11.98 \pm 0,27$ & $19.33 \pm 0,44$ & $135.65 \pm 3,11$ \\
5. & Cisadane Hilir & $12.94 \pm 0,29$ & $16.31 \pm 0,37$ & $88.58 \pm 2,03$ \\
\hline
\end{tabular}




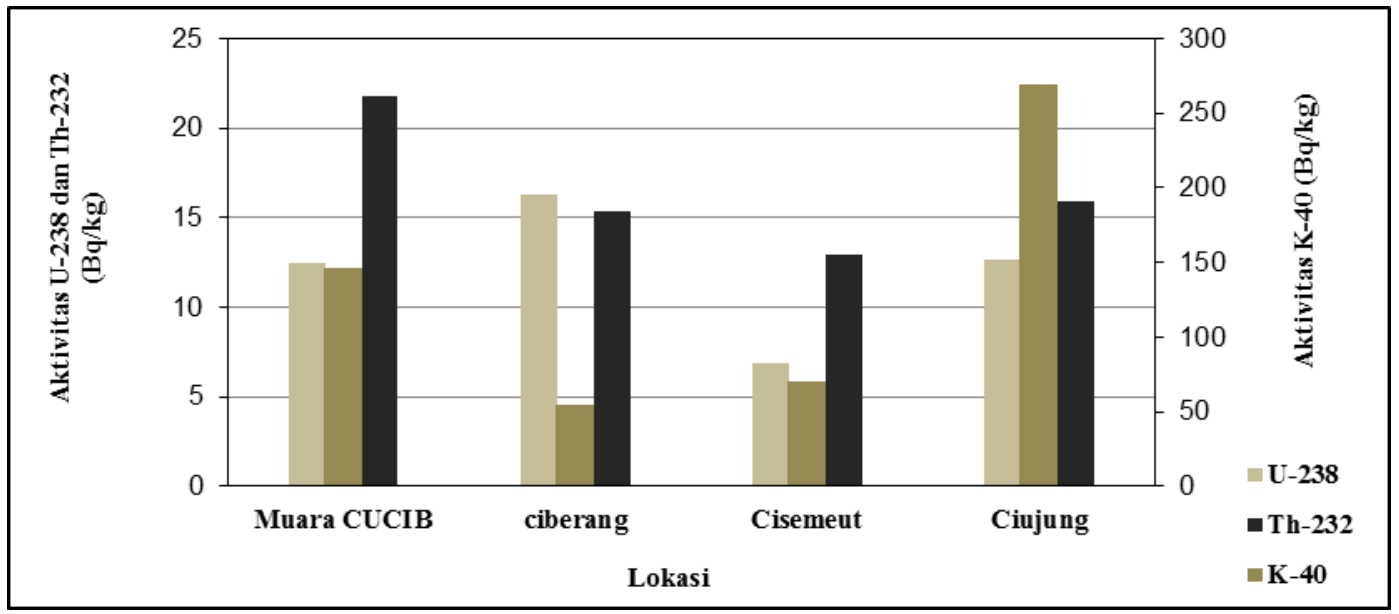

Gambar 1. Histogram konsentrasi radionuklida alam lokasi DAS Ciujung Hulu

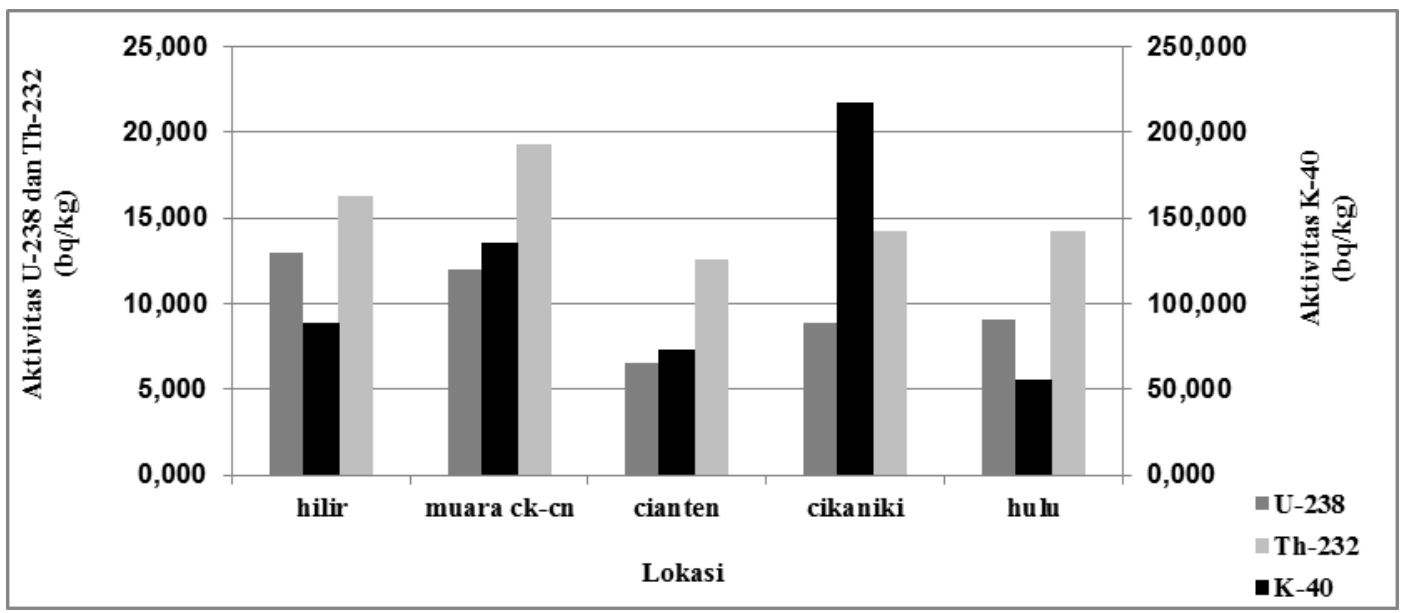

Gambar 2 . Histogram konsentrasi radionuklida alam lokasi DAS Cisadane Hulu

Apabila mengacu pada peraturan Bapeten tahun 1999 mengenai baku mutu lingkungan, ditetapkan keberadaan U-238 dan Th-232 di alam sebesar 25 $\mathrm{Bq} / \mathrm{kg}$, maka tingkat paparan radionuklida sekitar lokasi penelitian masih dalam batas aman. sehingga kegiatan masyarakat setempat berupa penambangan pasir dan batu langsung dari sungai masih diperbolehkan, sepanjang untuk kebutuhan hidup. Apabila nilai konsentrasi diatas batas toleransi, umumnya sekitar titik lokasi atau di daerah upstream terdapat sumber pencemar yang umumnya berasal dari kawasan industri seperti pabrik pupuk fosfat, industri kimia, fasilitas-fasilitas pengolahan limbah industri dan fasilitas industri lainnya, sedangkan K-40 belum diatur ${ }^{[14]}$.

Perbandingan konsentrasi rerata Th-232, Ra-226, dan K-40 dalam sedimen DAS Ciujung Hulu dan DAS Cisadane Hulu dan yang ditemukan dalam sedmen di tempat lain ditunjukkan pada tabel $6^{[15]}$.

Aktivitas konsentrasi Th-232 dan K-40 dalam sedimen DAS Ciujung Hulu 
dan DAS Cisadane Hulu lebih kecil dari konsentrasi rerata dunia. Aktivitas konsentrasi Ra-226 yang diukur dalam penelitian ini lebih kecil dari nilai aktivitas konsentrasi negara - negara lain, namun lebih besar
Tabel 6. Perbandingan konsentrasi rerata NORM dalam sedimen DAS Ciujung Hulu dan DAS Cisadane Hulu dan yang ditemukan dalam sedimen di tempat lain di dunia

\begin{tabular}{llcccl}
\hline No. & \multicolumn{1}{c}{ L okas i } & $\begin{array}{c}{ }^{132} \mathrm{Th} \\
(\mathrm{Bq} / \mathrm{kg})\end{array}$ & $\begin{array}{c}{ }^{220} \mathrm{Ra} \\
(\mathrm{Bq} / \mathrm{kg})\end{array}$ & $\begin{array}{c}{ }^{40} \mathrm{~K} \\
(\mathrm{~Bq} / \mathrm{kg})\end{array}$ & \\
\hline 1 & World average concentration & 40 & - & 370 & Firyal (1996) \\
2 & Kuwait national wide & $10 \pm 3,4$ & $11,8 \pm 4,0$ & $332 \pm 104$ & Firyal (1996) \\
3 & Spain river Tagus & 63 & 42 & 572 & Baeza (1992) \\
4 & Spain all soils & 49 & 45 & 650 & Baeza (1992) \\
5 & Lake Nasser, Egypt & 23 & 21 & 155 & Ibrahiem (1995) \\
6 & Lousiana, USA & 36 & 64 & 472 & Delune (1996) \\
7 & French river - 1 & 38 & 38 & 599 & Lambrechts (1992) \\
8 & French river - 2 & 44 & 28 & 700 & Descamps (1988) \\
9 & Belgium & $9-47$ & $13-43$ & $170-610$ & Deworm(1988) \\
10 & China & 90 & 50 & 527 & Ziqiang (1988) \\
11 & Greece-Milos island & 60 & 50 & 881 & Florou (1992) \\
12 & Bangladesh, Karnapuli river & 65,5 & 35,9 & 272 & Chowdhury (1999) \\
13 & Bangladesh, Shango river & 57,5 & 27,8 & 255 & Chowdhury (1999) \\
14 & DAS Ciujung Hulu, Banten & $16 \pm 0,74$ & $13 \pm 0,64$ & $135 \pm 0,53$ & Penelitian (2017) \\
15 & DAS Cisadane Hulu, Bogor & $15 \pm 0,35$ & $13 \pm 0,43$ & $114 \pm 0,61$ & Penelitian (2016)
\end{tabular}

dari negara Kuwait National Wide. Aktivitas konsentrasi Th-232 lokasi penelitian berada dalam kisaran yang diukur di tempat lain (Belgium) yaitu (947) $\mathrm{Bq} / \mathrm{kg}$.

Aktivitas Radium ekivalen (Ra eq), indeks bahaya radiasi (lyr), indeks bahaya internal (Ibi), dan indeks bahaya eksternal (lbe)

Radium ekivalen dan kajian radiologi dalam sampel sedimen di kedua lokasi DAS Ciujung Hulu dan Cisadane Hulu disajikan pada tabel 7 dan 8 . Nilai radium ekivalen dalam sampel sedimen berkisar antara $34,799 \mathrm{bq} / \mathrm{kg}$ hingga $56,912 \mathrm{bq} / \mathrm{kg}$. Seluruh nilai $\mathrm{Ra}$ eq tidak berbahaya karena masih dibawah standar yang direkomendasikan oleh UNSCEAR yaitu sebesar $370 \mathrm{~Bq} / \mathrm{kg}$ ) ${ }^{[16] \text {. }}$

Dari hasil perhitungan Indeks bahaya radiasi (Іүг) seluruh sampel sedimen diperoleh nilai maksimum sebesar 0,4281 dan minimum sebesar 0,2544 . Kontribusi radionuklida radium, torium, dan kalium dalam sedimen terhadap tingkat bahaya radiasi menunjukkan bahwa nilai Iүг lebih kecil dari 1. Demikian juga pada tingkat bahaya radiasi internal (IBi) dan tingkat bahaya radiasi eksternal (Ibe) diperoleh kisaran nilai masing - masing sebesar 0,1241 hingga 0,1899 dan 0,0939 hingga 0,1495 . Tingkat bahaya radiasi internal dan eksternal yang dihasilkan dari radionuklida alam dalam sedimen diperoleh nilai lebih kecil dari 1 sehingga masih aman terhadap manusia [17]. 


\section{Uji Statistik}

Untuk mengetahui apakah terdapat perbedaan yang signifikan nilai-nilai $\mathrm{Ra}$ eq dan nilai tingkat bahaya radiasi antara lokasi DAS Ciujung Hulu dan DAS Cisadane Hulu, maka perlu dilakukan uji hipotesis $h_{0}$. Pada pengujian statistik digunakan metoda analisis varian dengan rancangan acak lengkap.

Tabel 7. Rerata nilai perhitungan $\mathrm{Ra}$ eq, Iүr, I Bi, Ibe sedimen DAS Ciujung Hulu

\begin{tabular}{|c|c|c|c|c|}
\hline Lokasi & Ra eq (bq/kg) & Іүг & Ibi & Ibe \\
\hline ciberang & & & & \\
\hline Ciujung & 55,377 & 0,4018 & 0,1844 & 0,1495 \\
\hline Ciberang & 41,699 & 0,2935 & 0,1545 & 0,1126 \\
\hline Cisemut & 35,642 & 0,2544 & 0,1280 & 0,0962 \\
\hline Ciujung & 56,912 & 0,4281 & 0,1899 & 0,1537 \\
\hline
\end{tabular}

Tabel 8. Nilai perhitungan Ra eq, Iүr, I Bi, Ibe dalam sedimen DAS Cisadane Hulu

\begin{tabular}{lcccc}
\hline \multicolumn{1}{c}{ Lokasi } & Ra eq $(\mathrm{bq} / \mathrm{kg})$ & Iүr & Ibi & lbe \\
\hline Cisadane hulu & 40,887 & 0,2877 & 0,1543 & 0,1104 \\
Cikaniki & 51,850 & 0,3856 & 0,1798 & 0,1400 \\
Cianten & 34,799 & 0,2490 & 0,1241 & 0,0939 \\
Muara cianten Cikaniki & 51,331 & 0,3720 & 0,1744 & 0,1386 \\
Cisadane hilir & 41,962 & 0,3009 & 0,1452 & 0,1133 \\
\hline
\end{tabular}

Pengujian statistik menggunakan metode analisis varian dengan rancangan acak lengkap bertujuan untuk melihat perbandingan antara antar perlakuan dan dalam perlakuan. Hasil perbandingan yang diperoleh disebut sebagai Fhitung akan dibandingkan dengan $F_{\text {tabel }}$ untuk menguji keberterimaan hipotesis. Jika pada tingkat kepercayaan $\alpha=5 \%$, $F_{\text {hitung }}$ lebih kecil dari $F_{\text {tabel }}$ maka hipotesis $h_{o}$ diterima yang menyatakan tidak terdapat perbedaan secara signifikan. Dari hasil perhitungan diperoleh nilai $F_{\text {hitung }}$ parameter $\mathrm{Ra}$ eq, Iүr, I $\mathrm{Bi}$, dan lbe berturut-turut adalah $0,88,0,88,0,57$, dan 0,88 , dan $F_{\text {tabel }}$ sebesar 4,30 disajikan pada tabel 9, 10, 11, dan 12. Berdasarkan hasil uji diperoleh bahwa nilai $F_{\text {hitung }}<F_{\text {tabel }}$, sehingga parameter parameter uji di kedua lokasi DAS tidak berbeda secara nyata.

Tabel 9. Analisis varian Ra eq lokasi DAS Ciujung Hulu dan DAS Cisadane

\begin{tabular}{lcrccc}
\hline Sumber variasi & \multirow{2}{*}{ DK } & \multicolumn{2}{c}{ JK } & KT J JK/DK & \multicolumn{2}{c}{ Hitung } & Tabel \\
\hline Antar perlakuan & 1 & 70,056 & 70,056 & 0,88 & 4,30 \\
Dalam perlakuan & 24 & 1903,270 & 79,302 & & \\
Jumlah & 25 & 1973,326 & & & \\
\hline
\end{tabular}


Tabel 10. Analisis varian (I $\left.\mathrm{Y}_{\mathrm{r}}\right)$ lokasi DAS Ciujung Hulu dan DAS Cisadane

\begin{tabular}{lccccc}
\hline Sumber variasi & \multirow{2}{*}{ DK } & \multirow{2}{*}{ JK } & KT= JK/DK & \multicolumn{2}{c}{ F } \\
\cline { 4 - 6 } & & & & Hitung & Tabel \\
\hline Antar perlakuan & 1 & 0,004304 & 0,00430 & 0,88 & 4,30 \\
Dalam perlakuan & 24 & 0,116498 & 0,00485 & & \\
Jumlah & 25 & 0,120802 & & & \\
\hline
\end{tabular}

Tabel 11. Analisis varian (Ibi) lokasi DAS Ciujung Hulu dan DAS Cisadane

\begin{tabular}{lccccc}
\hline Sumber variasi & DK & JK & KT = JK/DK & \multicolumn{2}{c}{$F$} \\
\cline { 4 - 6 } & & & & Hitung & Tabel \\
\hline Antar perlakuan & 1 & 0,00049 & 0,00049 & 0,57 & 4,30 \\
Dalam perlakuan & 24 & 0,02062 & 0,00085 & & \\
Jumlah & 25 & 0,02111 & & & \\
\hline
\end{tabular}

Tabel 12. Analisis varian (Ibe) lokasi DAS Ciujung Hulu dan DAS Cisadane

\begin{tabular}{lccccc}
\hline Sumber variasi & DK & JK & KT = JK/DK & \multicolumn{2}{c}{$F$} \\
\cline { 4 - 6 } & & & & Hitung & Tabel \\
\hline Antar perlakuan & 1 & 0,00052 & 0,00051 & 0,88 & 4,30 \\
Dalam perlakuan & 24 & 0,01387 & 0,00057 & & \\
Jumlah & 25 & 0,01439 & & & \\
\hline
\end{tabular}

\section{KESIMPULAN}

Konsentrasi radionuklida alam $\mathrm{U}$ 238, Th-232, dan K-40 yang diperoleh dari ke dua lokasi DAS sangat kecil dibawah baku mutu yaitu sebesar $25 \mathrm{~Bq} / \mathrm{kg}$ dan masih dibawah rata-rata dunia. Sebaran konsentrasi U-238 di kedua lokasi berkisar antara 6,38-17,67 Bq/kg, konsentrasi Aktivitas Th-232 dan K-40 masing-masing berkisar anatara 11,56-
$23,45 \mathrm{~Bq} / \mathrm{kg}$ dan $49,76-289,65 \mathrm{~Bq} / \mathrm{kg}$. Nilai Ra eq pada ke dua lokasi DAS berkisar antara 34,799 - 56,912 Bq/kg masih dibawa batas yang direkomemdasikan oleh UNSCEAR yaitu sebesar $370 \mathrm{Bg} / \mathrm{kg}$. Nilai indeks bahaya radiasi Іүг, indeks bahaya radiasi internal (Ibi), dan indeks bahaya radiasi eksternal (Ibe) di kedua lokasi DAS masing-masing $<1$ sehingga masih aman terhadap manusia. Dari hasil uji statistik terhadap parameter $\mathrm{Ra}$ eq dan tingkat 
bahaya radiasi tidak terdapat perbedaan yang signifikan antara ke dua lokasi DAS.

\section{UCAPAN TERIMA KASIH}

Penulis mengucapkan terima kasih kepada Bapak Darman dan Bapak Wagiyanto atas bantuannya dalam proses pengambilan sampel dan preparasi sampel.

\section{DAFTAR PUSTAKA}

[1] WIGMAN, "Sediment Transportation, Chapter 11 In Gray, D.M. (ed) Handbook on The Principles of Hydrology", Canadian National Committee for The International Hydrological Decade. J. M. 1970

[2] IAEA, "Naturally Occurring Radioactive Material (NORM), proceedings of the Fifth International Symposium on Naturally Occurring Radioactive Material". IAEA-Vienna. 2008.

[3] ZAPATA. F. "Handbook for the Assessment of Soil Erosion and Sedimentation Using Environmental Radionuclides." 2002

[4] Kunto Wiharto dan Syarbaini, "Potensi NORM Pada Industri Non-Nuklir Di Indonesia", "Prosiding Seminar Aspek Keselamatan Radiasi dan Lingkungan Pada Industri Non Nuklir", hal 1-13, 2003

[5] Sieman, K,. Esterlund, R.A.. Van Aarle. J., Knaaek. M,. Estmeier, W, Patzelt, $P$, "A New measurement of the gamma ray intensities of $\mathrm{Pa}-234$ Accompanying the decay of U-238", " Applied radiation and isotopes 43 (7), P 873-880", 1992

[6] P3KRBiN - BATAN, "Instruksi Kerja Analisis 228Th, 226Ra, 228Ra, dan 40K Pada Sampel Tanah, sedimen, dan Bahan Bangunan, Laboratorium KKL", Puslitbang Keselamatan Radiasi dan Biomedika Nuklir, Badan Tenaga Nuklir Nasional, Jakarta, 2003.
[7] S.A.MUJAHID., A. RAHIM. S. HUSSAIN and M. FAROOQ., Radiat. Prot. Dosim., $130: 2008$, pp $206-212$.

[8] Beretka, J. And Mathew, P.J., "Natural Radioactivity on Australian Building Materials, Industrial Wastes and By-Products. Health Physics", 48(1), P 87-95. 1985

[9] UNSCEAR, "Sources and Effects of lonizing Radiation. United Nations Scientific Committee Effects Of Atomic Radiation", Report to the General Assembly, United Nations, New York. 1993

[10] NEA-OECD. "Nuclear Energy Agency. Exposure to radiation from natural radioactivity in building materials. Report by NEA Group of Experts", OECD. Paris. 1979

[11] UNSCEAR 2000 "Sources and Effectsof lonizing Radiation". Vol.1. REPORT 2000

[12] Vidmar T., Kanisch G., and Vidmar G. "Calculation of true coincidence summing corrections for extended sources with Efftran", Applied Radiation and Isotopes 69, 908-911, 2011

[13] UNSCEAR, "United Nations Scientific Committee on The Effect of Atomic Radiation. Exposure from Natural Sources of Radiation". Report to the the General Assembly, United Nations, New York. 1988.

[14] Bapeten, Kep. Ka.Bapeten No. 02 /KaBAPETEN/V-99 tentang Baku Tingkat Radioaktivitas di Lingkungan, BAPETEN, Jakarta 1999.

[15] Bikit, J. Slivka, Lj. Conkic, M. Krmar, M. Veskovic, N. Zikic-Todorovic, E. Varga, S. Curcic, D. Mrdja. "Radioactivity of the Soil in Vojvodina Northern Province of Serbia and Montenegro". J.of Environmental Radioactivity.78.p.1119. 2005.

[16] "United Nations Scientific Committee on The Effect of Atomic Radiation UNSCEAR," Report to the General 
Assembly, Annex B ; Exposures from Natural Radiation Sources, 2000.

[17] UNSCEAR, "Sources and Effects of Ionizing Radiation Report to the
General Assembly". Scientific Committee on the on the Effects of Atomic Radiation UN, New York, 2000. 